\title{
Model Pembelajaran Program Ekstrakurikuler Bahasa Arab dan Implementasinya di Madrasah Aliyah Pesantren
}

\author{
Muti'ur Rahman \\ Universitas Islam Negeri Maulana Malik Ibrahim Malang \\ muthiur.rohman21@gmail.com \\ Ibnu Zulqarnain \\ Universitas Islam Negeri Maulana Malik Ibrahim Malang \\ ibnubacin11@gmail.com \\ Maftuhah \\ Universitas Islam Negeri Maulana Malik Ibrahim Malang \\ maftuhahsst@gmail.com \\ Zakiyah Arifa \\ Universitas Islam Negeri Maulana Malik Ibrahim Malang \\ arifazakiyah@uin-malang.ac.id
}

\begin{abstract}
Pesantren based madrasah makes the Arabic language as one of the essential things to be mastered by their students. Madrasah runs several Arabic programs to improve students' attention and proficiency of Arabic language through extracurricular activities outside the classroom that aim to enrich knowledge and channel students' interest and talents. However, among these various activities, many of it do not operate well because of lack of skills. The purpose of this study is to describe the implementation of extracurricular programs in MA Pesantren Nurul Ulum and the language learning models used. The research used the descriptive qualitative method. The data sources of this research are the instructors in the Arabic extracurricular program, the location, files and photos of activities that carried out by interview, observation, and documentation. The results of this study are the implementation of extracurricular programs in MA Pesantren Nurul Ulum by using various language learning models following the objectives of the activities; cooperative models in Arabic Olympics extracurricular, Taqdimul Qishshah, and Khithabah, communicativeeclectic and quantum models in quiz extracurricular. Diverse learning models make the learning process more varied for teachers
\end{abstract}


and students while train student competencies. Then it should be realized as a whole in Arabic language education.

Keywords: Arabic extracurricular, implementation, language learning models

\begin{abstract}
Abstrak
Madrasah berbasis pesantren menjadikan bahasa Arab sebagai salah satu hal yang penting untuk dikuasai oleh santrinya. Lembaga ini menjalankan beberapa program bahasa Arab guna meningkatkan perhatian dan kemahiran bahasa Arab santri melalui kegiatan ekstrakurikuler di luar kelas untuk pengayaan dan penyaluran minat dan bakat siswa. Meski demikian di antara berbagai kegiatan tersebut banyak yang tidak beroperasi dengan baik karena minim kecakapan dalam pelaksanaan. Tujuan dari penelitian ini adalah mengetahui pelaksanaan program ekstrakurikuler di MA Pesantren Nurul Ulum dan model pembelajaran bahasa yang digunakan. Metode penelitian yang digunakan adalah kualitatif deskriptif. Sumber data penelitian ini adalah para pengajar di program ekstrakurikuler bahasa Arab tersebut, lokasi kegiatan, file-file dan foto-foto kegiatan yang dikumpulkan dengan wawancara, observasi, dan dokumentasi. Hasil penelitian ini adalah pelaksanaan program ekstrakurikuler di MA Pesantren Nurul Ulum berjalan dengan model-model pembelajaran bahasa yang sesuai dengan tujuan kegiatan; Model Kooperatif pada ekstrakurikuler Olimpiade Bahasa Arab, Taqdimul Qishshah, dan Khithabah, Model KomunikatifEklektik dan Quantum pada ekstrakurikuler Cerdas Cermat. Modelmodel pembelajaran yang beragam menjadikan proses belajar mengajar lebih variatif bagi guru dan siswa sekaligus mengasah kompetensi siswa. Maka hal tersebut sebaiknya direalisasikan secara keseluruhan dalam pendidikan bahasa Arab.
\end{abstract}

Kata Kunci: ekstrakurikuler bahasa Arab, pelaksanaan, model pembelajaran bahasa

\title{
Pendahuluan
}

Kata "pelaksanaan" jika diterjemahkan ke dalam bahasa Inggris adalah implementation atau semakna dengan actuating yang diambil dari bahasa Latin, actuare $^{1}$. Pelaksanaan merupakan suatu gerakan usaha terhadap seluruh anggota

1 Maswan Ahmadi, Kurnia Istita'ah, Nur Rahmah Sholihah, dan Zakiyah Arifah, Penggerakan Program Bahasa Arab di Pondok Pesantren Modern, (Arabi: Journal of Arabic Studies, 2018), 3 (1), hlm. 72. 
agar mau berusaha mencapai tujuan dan menyesuaikannya dengan perencanaan. ${ }^{2}$ Dalam pengertian yang lebih luas, pelaksanaan dalam sebuah manajemen merupakan tahap lanjutan dari perencanaan dan pengorganisasian. Pelaksanaan dapat dimaknai dengan pengarahan, yakni gerakan yang dilakukan oleh atasan terhadap bawahan, dalam gerakan tersebut terdapat bimbingan, arahan, dan aturan setiap tugas yang akan dilaksanakan oleh seluruh anggota ${ }^{3}$. Koonzt dan Cyrill O’Donnell mendefinisikan pelaksanaan merupakan relasi antar aspek perseorangan yang muncul oleh adanya hubungan atasan kepada bawahan agar mampu memahami pembagian tugas yang efektif dan efisien. Maka pelaksanaan dipandang sebagai bagian yang terpenting dalam manajemen, sebab secara khusus berkaitan dengan orang. ${ }^{4}$

Pada tahap actuating, SDM (Sumber Daya Manusia) memegang peran sebagai penentu berhasil atau tidaknya sebuah pelaksanaan. Maka faktor penentu yang paling kuat pada tahap actuating adalah apakah ukuran kinerja SDM atau pekerja yang telah dipilih dan ditempatkan dalam organisasi menunjukkan performa yang terbaik atau sebaliknya, sebab faktor manusia merupakan kunci yang paling utama dalam proses actuating. ${ }^{5}$ Maka pelaksanaan menjadi sangat penting demi tercapai dan suksesnya suatu tujuan dalam sebuah manajemen program. Karena tanpa adanya pelaksanaan maka perencanaan tidak akan dapat terealisasi dan pengorganisasian tidak berarti apa-apa. Pelaksanaan sendiri juga tidak akan berjalan dengan baik tanpa ada tahap selanjutnya yaitu pengawasan.

Adapun pada pelaksanaan manajemen di sekolah, program pembelajaran dalam suatu pendidikan merupakan kegiatan wajib yang sudah diatur dalam UUD pasal 20, agar peserta didik dapat mengembangkan potensi yang ada dalam dirinya untuk mengembangkan pengendalian diri, spiritual keagamaan, kecerdasan, kepribadian, akhlak mulia, sera keterampilan yang diperlukan oleh dirinya sendiri, masyarakat, bangsa serta negara. Program pembelajaran akan lebih efektif dan lebih berhasil jika di tunjang dengan beberapa program, salah satunya adalah program ekstrakurikuler.

Di dalam golongan pengembangan diri tercakup oleh bimbingan dan konseling, dan kegiatan ekstrakurikuler. Makna dari istilah ekstrakurikuler adalah pengalaman di luar program kurikulum sekolah. Istilah ini dipakai dengan maksud kegiatan di luar ranah kurikulum sekolah dan mengarah pada peningkatan pengetahuan siswa dalam sudut pandang kognitif ataupun afektif, menumbuhkan minat dan bakat siswa sebagai usaha membina pribadi mereka

2 Baharuddin dan Moh. Makin, Manajemen Pendidikan Islam, (Malang: UIN Maliki Press, 2016), hlm. 159.

${ }^{3}$ Maswan Ahmadi, dkk, op.cit. hlm. 72.

${ }^{4}$ Baharuddin dan Moh. Makin, op.cit., hlm. 159-160.

5 Amri Yusuf Lubis, Pelaksanaan Manajemen Kurikulum pada SMA Negeri 1 Buengcala Kabupaten Aceh Besar, (Banda Aceh: Jurnal Administrasi Pendidikan Pascasarjana Universitas Syiah Kuala, 2015), 3 (1), hlm. 19. 
mencapai kepribadian manusia seutuhnya, mengetahui, memahami, dan dapat menghubungkan antara satu mata pelajaran dengan mata pelajaran lainnya ${ }^{6}$.

Program ekstrakurikuler sendiri merupakan suatu kegiatan atau rangkaian kegiatan yang diadakan untuk menunjang aspek-aspek tertentu dalam muatan kurikulum, kegiatan ini juga untuk pengembangan kemampuan peserta didik dari segi potensi, kebutuhan, bakat dan minat mereka, dengan adanya penyelenggaraan kegiatan khusus oleh tenaga kependidikan yang mempunyai kemampuan serta wewenang, atau dilaksanakan oleh peserta didik itu sendiri ${ }^{7}$. Pelaksanaan ekstrakurikuler dalam sebuah sekolah menjadi kegiatan pengembangan diri yang berupaya membentuk watak dan karakter siswa ${ }^{8}$. Ekstrakurikuler adalah suatu kegiatan yang dilaksanakan di luar program yang tertera dalam kurikulum seperti latihan kepemimpinan dan pembinaan siswa9 Kegiatan ini dilaksanakan oleh para guru dan pembina ekstrakurikuler yang kemudian diatur oleh wakil kepala sekolah bagian kesiswaan ${ }^{10}$.

Badan Standar Nasional Pendidikan (BSNP) dan Kurikulum Tingkat Satuan Pendidikan (KTSP) (2006: 13) merumuskan beberapa fungsi dari kegiatan ekstrakurikuler, yaitu:

1. Pengembangan, yaitu fungsi untuk mengembangkan kecakapan dan kreativitas siswa sesuai dengan potensi, minat, dan bakatnya.

2. Sosial, yaitu fungsi untuk menumbuhkan kecakapan dan rasa tanggung jawab siswa.

3. Rekreatif, yaitu fungsi untuk menghadirkan suasana yang santai, menyenangkan, dan mengembirakan sehingga menyokong proses perkembangannya.

4. Persiapan karir, yaitu fungsi untuk menumbuhkan persiapan siswa dalam berkarir ${ }^{11}$.

Program ekstrakurikuler sangat beragam dan salah satunya adalah ekstrakurikuler kebahasaan. Pelaksanaan program ekstrakurikuler kebahasaan ini akan berjalan dengan baik jika beberapa komponen di dalamnya memahami manajemen dengan baik, karena jika tidak, maka pelaksanaan tersebut akan terbentur dengan masalah-masalah yang sulit untuk dipecahkan.

${ }^{6}$ Moh. Uzer dan Lilis, Upaya Optimalisasi Kegiatan Belajar Mengajar, (Bandung: PT. Remaja Rosdakarya, 1993), hlm. 22.

7 Novan Ardy Wiyani, Menumbubkan Pendidikan Karakter di SD (Konsep, Praktek dan Strategi), (Jogjakarta: Ar-Ruzz Media, 2013), hlm. 108.

8 Sus Ria Viningsih, Pelaksanaan Program Pengembangan Diri Siswa di Sekolah Menengah Atas Negeri 1 Timpeh Kecamatan Timpeh Kabupaten Dharmasraya, Jurnal Bahana Manajemen Pendidikan, 2013), 1 (1), hlm. 260.

9 Ibid., hlm. 260-261.

${ }_{10}$ M. Yudha Saputra, Pengembangan Kegiatan Ko dan Ekstrakurikuler, Jakarta: Depdiknas, 1998), hlm. 8.

11 Sus Ria Viningsih, op.cit., hlm. 261. 
Pembelajaran bahasa Arab dari satu sekolah dengan sekolah lain berbeda, hal tersebut disebabkan oleh orientasi atau tujuan yang ingin dicapai masing-masing sekolah juga berbeda, sehingga program ekstrakurikulernya juga berbeda, begitu pula dari segi kurikulum, sumber belajar, pengajar, metode, media dan evaluasinya. Keseriusan mencapai tujuan pengajaran akan berdampak besar bagi kepala sekolah dan para guru yang mempunyai hubungan terhadap program tersebut untuk me-manage-nya dengan baik sehingga pelaksanaannya juga akan baik serta masalah-masalah yang ditemui di tengah pelaksanaannya akan mudah di atasi, semua ini tentunya akan berpengaruh pada semangat peserta didik dan hasil akhir yang mereka capai.

Pelaksanaan sebuah program kebahasaan tentu memiliki suatu bentuk atau model pembelajaran bahasa yang menjadi dasar dari langkah demi langkahnya. Model-model pembelajaran bahasa tersebut di antaranya adalah Model Komunikatif-Eklektik, Model Kooperatif, Model Kontekstual, Model Quantum. Ketika sebuah pelaksanaan dibentuk dengan model yang tepat, maka hasil yang diperoleh akan menjadi lebih baik. Maka model pembelajaran bahasa menjadi sangat penting untuk diterapkan dan dievaluasi.

Model Komunikatif-Eklektik adalah gabungan antara Model Komunikatif dan Eklektik. Model Komunikatif merupakan pendekatan di dalam pembelajaran bahasa yang mengutamakan kemampuan berkomunikasi dan berinteraksi dalam situasi keseharian ${ }^{12}$ Sedangkan Eklektik adalah metode pembelajaran bahasa yang juga dapat dimaknai dengan metode campuran. Metode ini menekankan kemahiran berbicara, membaca, menulis dan menyerap pemahaman tertentu dalam proses pembelajaran ${ }^{13}$. Kegiatan pembelajaran seperti ini akan menjadi kegiatan yang bervariasi dan tidak tertumpu pada kegiatan tunggal sehingga metode ini membuat kegiatan pembelajaran menumbuhkan motivasi peserta $\operatorname{didik}^{14}$.

Model Kooperatif merupakan pembelajaran yang menempatkan siswa dalam kelompok kecil yang saling membantu dalam belajar. Model ini dikembangkan berdasarkan teori belajar kooperatif konstruktivis ${ }^{15}$. Kegiatan pembelajaran dalam model ini mengutamakan kesadaran siswa agar mampu belajar berpikir, menyelesaikan masalah, dan mempraktikkan pengetahuannya,

${ }^{12}$ Sugiono, Meningkatkan Hasil Belajar Bahasa Indonesia Materi Melaporkan Isi Buku Melalui Pendekatan Komunikatif Metode SQ2R pada Siswa Kelas 6 SDN Kramat Sukoharjo 03 Jember, Jember: Jurnal Pancaran Pendidikan, 2014), 3 (3), hlm. 124.

13 Ahmad Izzan, Metodologi Pembelajaran Bahasa Arab, (Bandung: Humaniora, 2009), hlm. 111.

14 Acep Hermawan, Metodologi Pembelajaran Bahasa Arab, (Bandung: Remaja Rosdakarya, 2011), hlm. 198.

${ }^{15}$ Lindarti, Achmad A. Hinduan, Raden Oktova, Penerapan Pembelajaran Kooperatif STAD (Student Teams Achievement Division) dalam Upaya Meningkatkan Hasil Belajar Fisika pada Konsep Optika Geometris Kelas X SMA, (Yogyakarta: Jurnal BFI, 2010), 2 (2), hlm. 30. 
sehingga ia merasa bangga karena ikut serta memberikan pengetahuannya kepada teman yang lain dalam kelompok belajarnya. Model ini juga mengarahkan siswa dapat belajar melakukan refleksi terhadap jalan pemikirannya sendiri dan mengaitkan pengalamannya dengan pengalaman anggota lain di dalam diskusi kelompok, diskusi membangun pengetahuan, dan memecahkan masalah $^{16}$.

Model kontekstual merupakan model pembelajaran yang berupa usaha pendidik dalam membimbing pemahaman peserta didik terhadap kaitan atau hubungan materi pembelajaran yang ia pelajari, yaitu dengan menjalankan sebuah pendekatan yang menyuguhkan kesempatan bagi peserta didik agar dapat mengaplikasikan materi yang dipelajarinya di sekolah. Kemudian model pembelajaran ini juga tertumpu pada pertumbuhan ilmu, pemahaman, kecakapan peserta didik, serta pemahaman kontekstual peserta didik terkait hubungan materi pelajaran yang ia pelajari dengan lingkungan sekitarnya. Proses pembelajaran seperti ini tentu akan lebih berkualitas ketika pendidik ikut lebih menekankan agar peserta didik memahami kaitan apa yang dipelajari di kelas dengan keadaan di dunia nyata yang menjadi tempat materi pelajaran tersebut akan direalisasikan ${ }^{17}$.

Model quantum adalah upaya untuk menciptakan berbagai macam interaksi yang terdapat pada proses pembelajaran dengan berbagai nuansa agar suasana pembelajaran menjadi lebih meriah, dan melibatkan segala relevansi, interaksi dan perbedaan yang dapat membuat proses pembelajaran menjadi lebih maksimal ${ }^{18}$. Model ini juga diartikan sebagai taktik, pedoman, strategi, dan segala proses pembelajaran yang mampu mengasah pemikiran dan kekuatan ingatan, serta membangun proses pembelajaran sebagai kegiatan yang bermanfaat dan menyenangkan ${ }^{19}$.

Program kebahasaan yang ditunjang dengan kegiatan ekstrakurikuler di Madrasah Aliyah Nurul Ulum yang merupakan suatu lembaga di bawah naungan pesantren Madrasah Aliyah Nurul Ulum merupakan suatu lembaga di bawah naungan pesantren modern, dalam artian sistem pembelajarannya sudah menggunakan media dan metode pengajaran yang modern dan memiliki sarana prasarana yang cukup memadai ${ }^{20}$. Sudah dianggap sangat baik dan terbilang

16 Wagiran, Meningkatkan Keaktifan Mahasiswa dan Reduksi Miskonsepsi Melalui Pembelajaran Konstruktivistik. Model Kooperatif Berbantuan Modul, (Malang: Jurnal Ilmu Pendidikan, 2006), 13 (1), hlm. 27.

${ }^{17}$ Sumiati dan Asra, Metode Pembelajaran, (Bandung: CV. Wacana Prima, 2009), hlm. 14.

18 B. De Porter, M. Reardon, dan SS. Nourie, Quantum Teaching (Mempraktikkan Quantum Learning di Ruang-ruang Kelas), Terjemahan Ary Nilandari, (Bandung: Kaifa, 2014), hlm. 32.

19 Jumadi, Peningkatan Pemahaman Siswa Materi Kenampakan Alam Melalui Model Quantum Learning Siswa Kelas IV SDN Gebangsari 01 Semarang Tabun Ajaran 2010/2011, (Semarang: Jurnal Media Penelitian Pendidikan, 2012), 6 (2), hlm. 80.

${ }^{20}$ https://nurululum.wordpress.com/ma-nurul-ulum/, diakses pada 31 Oktober 2018. 
berhasil, karena selain menunjang terhadap mata pelajaran bahasa Arab yang ada, program ini telah banyak mengantarkan peserta didiknya meraih berbagai penghargaan dan medali dalam perlombaan bahasa Arab, baik dari khithabah, taqdimul qishshoh, imathah dan lain sebagainya.

Hasil tinjauan peneliti, bahwa pelaksanaan program ekstrakurikuler bahasa Arab tidak hanya berupa satu kegiatan, melainkan juga beberapa takhashshush yang tergantung pada minat peserta didik. Kegiatan ini diwajibkan bagi seluruh peserta didik sehingga tak heran jika MA Pesantren Nurul Ulum ini mempunyai para santri dengan keahlian masing-masing di bidang bahasa Arab. Berdasarkan keterangan di atas, maka peneliti ingin mencoba menyoroti pelaksanaan program ekstrakurikuler bahasa Arab di MA Pesantren Nurul Ulum, dengan fokus pembahasan: 1) Bagaimana pelaksanaan program ekstrakurikuler bahasa Arab di MA Pesantren Nurul Ulum? 2) Apa model pembelajaran bahasa yang digunakan dalam pelaksanaan program ekstrakurikuler bahasa Arab di MA Pesantren Nurul Ulum?

Adapun metode yang digunakan dalam penelitian ini adalah kualitatif deskriptif, karena peneliti ingin mendeskripsikan pelaksanaan program ekstrakurikuler dan model pembelajaran bahasa Arab di MA Pesantren Nurul Ulum. Metode pengumpulan data menggunakan wawancara kepada para pengajar di program ekstrakurikuler bahasa Arab tersebut, observasi dengan secara langsung turun ke lokasi kegiatan dan dokumentasi baik pengumpulan file-file dan foto-foto kegiatan. Kemudian teknik analisis data menggunakan analisis deskriptif, yaitu dengan $3 \operatorname{tahapan}^{21}$; 1) reduksi kata, yaitu memilah data yang penting dan membuang yang tidak dibutuhkan sehingga bisa fokus terhadap masalah yang diteliti, 2) penyajian kata, yaitu menyajikan data yang sudah dipilah dengan berbagai bentuk pola sajian sehingga mudah dipahami, 3) penarikan kesimpulan, di mana setelah data dapat dipahami dengan baik maka selanjutnya disimpulkan, dan kesimpulan itu akan dapat dipercaya ketika didukung oleh bukti-bukti yang valid dan konsisten saat peneliti kembali ke lapangan untuk mengumpulkan data.

\section{Hasil dan Pembahasan}

Peneliti melakukan observasi, wawancara dan dokumentasi di Madrasah Aliyah Nurul Ulum Malang terletak di Kebonsari Sukun Malang. Nurul Ulum 1 adalah Madrasah pusat yang sudah memiliki beberapa sekolah cabang yang terletak di Malang. Madrasah telah berhasil merebut perhatian masyarakat dengan prestasi yang diraihnya baik dalam perlombaan regional maupun nasional. Madrasah Aliyah Nurul Ulum ini memiliki nilai lebih dalam pembelajaran Bahasa Arab. Santri Madrasah Aliyah Nurul Ulum selain

${ }^{21}$ Sugiyono, Metode Penelitian Kualitatif, Kuantitatif, dan R\&D, (Bandung: IKAPI, 2017), hlm. 246. 
mengikuti kurikulum pembelajaran bahasa Arab di kelas, mereka juga memiliki kesempatan untuk lebih mendalami bahasa Arab dengan beberapa macam program pembelajaran yang dilaksanakan di luar kelas yang di desain dengan ekstrakurikuler.

Berdasarkan wawancara dengan salah satu pelatih ekstrakurikuler yaitu ustadzah Ana menjelaskan bahwa para santri memiliki kebebasan dalam menentukan bidang yang mereka minati. Ekstrakurikuler di Madrasah sangat beragam. MA Pesantren Nurul Ulum memiliki 10 ekstrakurikuler yang terbagi menjadi dua bidang yaitu olimpiade dan seni. Bahasa Arab sendiri masuk pada kedua jenis tersebut. Program ekstrakurikuler bahasa Arab di Madrasah Aliyah Nurul Ulum ada empat jenis yaitu khitabah, olimpiade bahasa Arab, cerdas cermat, dan taqdimul qisshoh. Ekstrakurikuler bahasa Arab dibentuk pada tahun 2017. Berikut adalah keterangan dari ekstrakurikuler bahasa Arab:

\begin{tabular}{|c|c|c|c|c|c|}
\hline No & Kegiatan & $\begin{array}{l}\text { Deskripsi } \\
\text { Kegiatan }\end{array}$ & Materi & $\begin{array}{l}\text { Proses } \\
\text { Pembelajaran }\end{array}$ & Waktu \\
\hline 1 & Khithabah & $\begin{array}{l}\text { Kegiatan pidato } \\
\text { berbahasa Arab. } \\
\text { Kegiatan ini } \\
\text { bertujuan agar } \\
\text { santri Madrasah } \\
\text { mampu } \\
\text { menyampaikan } \\
\text { ide, pikiran } \\
\text { melalui kalimat } \\
\text { yang tersusun } \\
\text { sistematis, dan } \\
\text { para pendengar } \\
\text { dapat menerima } \\
\text { statemennya dan } \\
\text { mengikuti } \\
\text { ajakannya. }\end{array}$ & $\begin{array}{l}\text { Materi yang } \\
\text { diberikan } \\
\text { pelatih adalah } \\
\text { materi } \\
\text { dengan tema } \\
\text { yang umum } \\
\text { digunakan } \\
\text { dalam } \\
\text { perlombaan } \\
\text { seperti materi } \\
\text { tentang peran } \\
\text { pemuda, } \\
\text { toleransi } \\
\text { beragama, } \\
\text { kenegaraan, } \\
\text { dan lain } \\
\text { sebagainya. }\end{array}$ & $\begin{array}{l}\text { Pelatih memberi } \\
\text { teks bahasa } \\
\text { Indonesia, dan } \\
\text { tugas dari } \\
\text { peserta } \\
\text { ekstrakurikuler } \\
\text { adalah } \\
\text { menerjemahkan, } \\
\text { mengulangi, } \\
\text { menghafal, dan } \\
\text { latihan/praktek. } \\
\text { Untuk satu judul } \\
\text { teks pidato } \\
\text { membutuhkan } \\
\text { paling sedikitnya } \\
\text { tiga pertemuan. } \\
\text { Teks pidato } \\
\text { yang pelatih } \\
\text { berikan tidak } \\
\text { terdapat } \\
\text { patokan atau } \\
\text { kurikulum } \\
\text { khusus yang } \\
\text { digunakan } \\
\text { dalam menentukan } \\
\text { mana }\end{array}$ & $\begin{array}{l}\text { Sabtu, } \\
\text { pukul } \\
10.15- \\
11.15 \\
\text { WIB }\end{array}$ \\
\hline
\end{tabular}




\begin{tabular}{|c|c|c|c|c|c|}
\hline & & & & $\begin{array}{lr}\text { judul teks, } & \text { materi } \\
\text { semua } & \text { kembali kepada } \\
\text { prioritas pelatih. }\end{array}$ & \\
\hline 2 & $\begin{array}{l}\text { Olimpiade } \\
\text { Bahasa } \\
\text { Arab }\end{array}$ & $\begin{array}{l}\text { Ekstrakurikuler } \\
\text { ini merupakan } \\
\text { kegiatan } \\
\text { mengasah semua } \\
\text { pengetahuan } \\
\text { tentang } \\
\text { kebahasaan } \\
\text { khususnya } \\
\text { bahasa Arab, } \\
\text { baik meliputi } \\
\text { unsur-unsur } \\
\text { kebahasaan dan } \\
\text { keterampilan } \\
\text { bahasa Arab. } \\
\text { Tujuan dari } \\
\text { kegiatan ini } \\
\text { adalah agar santri } \\
\text { terbiasa dalam } \\
\text { menjawab soal- } \\
\text { soal kebahasaan } \\
\text { dan menguji } \\
\text { kemampuannya } \\
\text { dalam bentuk } \\
\text { latihan soal. }\end{array}$ & $\begin{array}{l}\text { Materi } \\
\text { pembelajaran } \\
\text { kegiatan ini } \\
\text { mencakup } \\
\text { semua } \\
\text { pengetahuan } \\
\text { bahasa seperti } \\
\text { kaidah bahasa } \\
\text { Arab Nabwu } \\
\text { dan Sharaf, } \\
\text { mufradat, dan } \\
\text { mahfudzat. } \\
\text { Buku yang } \\
\text { digunakan } \\
\text { dalam proses } \\
\text { pembelajaran } \\
\text { nya adalah } \\
\text { kitab Al- } \\
\text { Arabiyah } \\
\text { Baina } \\
\text { Yadaika. }\end{array}$ & $\begin{array}{l}\text { Pembahasan } \\
\text { setiap tema } \\
\text { dalam buku } \\
\text { beserta latihan- } \\
\text { latihannya. } \\
\text { Pelatih memberi } \\
\text { tugas-tugas } \\
\text { terkait tema dan } \\
\text { materi yang } \\
\text { disampaikan } \\
\text { setiap } \\
\text { minggunya. }\end{array}$ & $\begin{array}{l}\text { Jum'at, } \\
\text { pukul } \\
09.00- \\
10.00 \\
\text { WIB }\end{array}$ \\
\hline 3 & $\begin{array}{l}\text { Cerdas } \\
\text { Cermat }\end{array}$ & $\begin{array}{l}\text { Ekstrakurikuler } \\
\text { ini adalah } \\
\text { kegiatan menguji } \\
\text { ketangkasan } \\
\text { santri dalam } \\
\text { menguji } \\
\text { kepekaannya } \\
\text { terhadap bahasa } \\
\text { Arab. }\end{array}$ & $\begin{array}{l}\text { Materi yang } \\
\text { dipelajari } \\
\text { meliputi: } \\
\text { pengetahuan } \\
\text { Islam (sejarah } \\
\text { kebudayaan } \\
\text { Islam), kaidah } \\
\text { bahasa Arab } \\
\text { (Nahwu dan } \\
\text { Sharf), } \\
\text { mufradat, dan } \\
\text { mahfuzhat. }\end{array}$ & $\begin{array}{l}\text { Batasan materi } \\
\text { pada kegiatan } \\
\text { ini tidak } \\
\text { terdapat } \\
\text { kurikulum dan } \\
\text { rancangan } \\
\text { pembelajaranny } \\
\text { a masih bersifat } \\
\text { subjektif pelatih, } \\
\text { contoh pada } \\
\text { pertemuan } \\
\text { pertama di } \\
\text { minggu pertama } \\
\text { bulan Agustus, } \\
\text { pelatih ingin }\end{array}$ & $\begin{array}{l}\text { Sabtu, } \\
\text { pukul } \\
10.15- \\
11.15 \\
\text { WIB }\end{array}$ \\
\hline
\end{tabular}




\begin{tabular}{|c|c|c|c|c|c|}
\hline & & & & $\begin{array}{l}\text { memberi materi } \\
\text { tentang Nahwu, } \\
\text { sedangkan pada } \\
\text { pertemuan } \\
\text { selanjutnya } \\
\text { dilanjutkan } \\
\text { dengan latihan } \\
\text { mufradat dan } \\
\text { mahfuzhat, dan } \\
\text { demikian } \\
\text { sampai batas } \\
\text { waktu yang } \\
\text { ditentukan. }\end{array}$ & \\
\hline 4 & $\begin{array}{l}\text { Taqdimul } \\
\text { Qisshoh }\end{array}$ & $\begin{array}{l}\text { Kegiatan dimana } \\
\text { seseorang dapat } \\
\text { menceritakan } \\
\text { kembali sebuah } \\
\text { teks atau cerita } \\
\text { bahasa Arab } \\
\text { dengan bentuk } \\
\text { drama tunggal, } \\
\text { baik cerita yang } \\
\text { sudah ada atau } \\
\text { cerita yang } \\
\text { merupakan } \\
\text { perluasan dari } \\
\text { cerita pendek } \\
\text { bahasa Arab. }\end{array}$ & $\begin{array}{l}\text { Materi yang } \\
\text { digunakan } \\
\text { biasanya } \\
\text { diadopsi dari } \\
\text { buku-buku } \\
\text { hikmah } \\
\text { seperti } \\
\text { Qira'atur } \\
\text { Rasyiddah, dan } \\
\text { Al Milal wa } \\
\text { An Nihal. }\end{array}$ & $\begin{array}{l}\text { Materi disiapkan } \\
\text { oleh pelatih, dan } \\
\text { tugas dari } \\
\text { peserta adalah } \\
\text { menerjemahkan, } \\
\text { memahami, dan } \\
\text { praktek yang } \\
\text { dalam } \\
\text { pelaksanaannya } \\
\text { dibagi menjadi } \\
\text { dua pertemuan, } \\
\text { pertemuan } \\
\text { pertama yaitu } \\
\text { penerjemahan } \\
\text { teks dan } \\
\text { pemahamannya, } \\
\text { sedangkan } \\
\text { pertemuan } \\
\text { selanjutnya } \\
\text { adalah praktek. }\end{array}$ & $\begin{array}{l}\text { Sabtu, } \\
\text { pukul } \\
10.15- \\
11.15 \\
\text { WIB }\end{array}$ \\
\hline
\end{tabular}

Menurut hasil observasi peneliti, pelaksanaan ekstrakurikuler di atas relatif stabil dan kegiatan berlangsung setiap minggunya. Namun dalam setiap kegiatan mustahil untuk tidak ditemukan sebuah permasalahan. Masalah yang sering muncul adalah perubahan waktu pelaksanaan ekstrakurikuler dikarenakan pelatih yang tidak dapat hadir pada hari yang ditentukan, dan tidak adanya konfirmasi terlebih dahulu sehingga peserta sudah hadir di kelas dan harus kembali ke kamar, ketidakhadiran pelatih menjadi masalah umum di semua cabang ekstrakurikuler. Masalah tersebut tidak menjadi signifikan karena kegiatan tetap berlangsung di hari lain dalam minggu tersebut. 
Ekstrakurikuler yang dipilih oleh siswi dimasukkan pada nilai rapor, aspek penilaian dilihat dari tingkat kehadiran dan keaktifan siswi di kelas. Pihak yang terlibat dalam kesuksesan dilaksanakannya ekstrakurikuler adalah guru pelatih yang khusus didatangkan dari luar sekolah, Waka kesiswaan. Ekstrakurikuler bahasa Arab dibentuk pada tahun 2017 dengan sistem pilihan, siswi boleh memilih untuk mengikuti dan diperbolehkan untuk tidak berpartisipasi dalam kegiatan ekstrakurikuler. Pada tahun 2018, penilaian ekstrakurikuler dicantumkan dalam rapor, dengan kata lain tahun ini adalah tahun pertama rapor berisi nilai ekstrakurikuler.

Adapun catatan bagi siswi dalam mengikuti ekstrakurikuler adalah sebagai berikut:

1. Seluruh siswa diwajibkan mengikuti salah satu kegiatan ekstrakurikuler.

2. Kegiatan ekstrakurikuler masuk dalam rapor dengan ketentuan jika selalu aktif akan mendapatkan nilai A.

3. Siswi yang tidak aktif mengikuti kegiatan ekstrakurikuler akan mendapat teguran bertahap.

4. Kelas yang siswinya tidak aktif dalam mengikuti ekstrakurikuler akan diumumkan ketika apel pagi (hari Senin).

5. Siswi yang berpartisipasi dalam kegiatan ekstrakurikuler akan menjadi perwakilan MA Pesantren Nurul Ulum di setiap perlombaan luar sekolah.

6. Setiap siswi yang hadir dalam pembinaan harus mengisi daftar hadir.

7. Disarankan bagi setiap kelas mengikuti semua cabang ekstrakurikuler.

Berdasarkan hasil wawancara dengan siswi, dampak ekstrakurikuler bahasa Arab khususnya di bidang olimpiade sangat terasa di dalam menunjang pemahaman dan kemampuan siswi pada mata pelajaran bahasa Arab di sekolah dan memotivasi siswi untuk lebih percaya diri dengan kemampuan yang dimilikinya.

Selain masalah juga terdapat prestasi-prestasi yang telah dicapai oleh peserta ekstrakurikuler di beberapa cabang lomba. Menurut dokumentasi sekolah tahun 2018, prestasi-prestasi yang pernah diraih diantaranya sebagai berikut:

1. Juara 1 Musabaqah Fabmil Qur'an di Universitas Brawijaya (2017)

2. Juara 1 lomba khitabah di Jember (2018)

3. Juara harapan 1 cabang Lomba Khitabah di Madrasah Aliyah Negeri Malang 1 (2018)

4. Juara 1 Musabaqah Fabmil Qur'an di Universitas Negeri Malang (2018)

5. Juara III lomba Qiraatul Akhbar di Pekan Arabi Universitas Negeri Malang (2018)

6. Juara harapan III lomba Qiraatul Akbbar di Pekan Arabi Universitas Negeri Malang (2018) 
7. Juara II lomba Qiraatul Akbbar di GAZA (Gebyar Apresiasi Khazanah Arab) Universitas Islam Maulana Malik Ibrahim Malang (2018).

Pada umumnya dalam pendelegasian lomba, dapat dipastikan setiap sekolah menginginkan yang terbaik pada hasil akhirnya. Namun, secara khusus MA Pesantren Nurul Ulum tidak memasang target khusus yang wajib diperoleh oleh peserta lomba di luar sekolah, tujuan utamanya adalah siswi memiliki pengalaman dan dapat membaginya kepada teman-temannya. Hal ini dibuktikan bahwa delegasi lomba di setiap cabang selalu mengalami perubahan dan tidak terpaku pada satu anak. Seluruh peserta lomba pada cabang lomba yang berbeda-beda di atas diambil dari siswi yang mengikuti ekstrakurikuler bahasa Arab.

Menurut wawancara dengan salah dua peserta ekstrakurikuler khithabah yaitu saudari FR dan NN bahwasanya motivasi keikutsertaannya dalam ekstrakurikuler adalah besarnya minat dan kecintaannya terhadap bahasa Arab, dan keinginannya untuk mengetahui dunia luar yang dapat diperoleh dengan mengikuti perlombaan. "Sebagaimana santri pondok yang lain, saya senang jika mendapatkan untuk bisa keluar dari pondok", ujarnya. NN menambahkan bahwa "ekstrakurikuler pada tabun ini (2018) diwajibkan untuk seluruh siswi dan saya lebih suka kegiatan pembinaan pembelajaran daripada kegiatan seni yang pelaksanaannya di ruang terbuka seperti banjari, kaligrafi, dan lain sebagainya".

Berdasarkan penelitian yang dilakukan pada pelaksanaan ekstrakurikuler di MA Pesantren Nurul Ulum 1 Malang terdapat dua jenis ekstrakurikuler yang dimiliki yaitu pada bidang olimpiade dan seni, empat diantaranya adalah ekstrakurikuler bahasa Arab yang juga termasuk di dalam kedua jenis tersebut. Pertama, yaitu di bidang olimpiade adalah olimpiade bahasa Arab, sedangkan pada bidang seni ada kbitabah (pidato bahasa Arab), taqdimul qisshoh, dan cerdas cermat. Hal tersebut sesuai dengan pengertian kurikulum sebagai kegiatan di luar ranah kurikulum sekolah dan mengarah pada peningkatan pengetahuan siswa dalam sudut pandang kognitif ataupun afektif, menumbuhkan minat dan bakat siswa sebagai usaha membina pribadi mereka mencapai kepribadian manusia seutuhnya, mengetahui, memahami, dan dapat menghubungkan antara satu mata pelajaran dengan mata pelajaran lainnya. ${ }^{22}$

Menurut Geroge R. Terry yang dikutip oleh Baharuddin dan Moh. Makin $^{23}$ berpendapat bahwa sukses dalam manajemen sebagian besar dipengaruhi beberapa hal:

1. Memperoleh orang-orang yang ahli

2. Mengutarakan keinginan dan pencapaian yang akan diraih.

3. Menjelaskan bagaimana cara mengerjakan apa yang menjadi tujuan kita.

${ }^{22}$ Moh. Uzer dan Lilis, opcit, hlm. 22.

${ }^{23}$ Baharuddin dan Moh. Makin, op.cit., hlm. 160. 
4. Memberikan otoritas terhadap mereka

5. Menginspirasi mereka dengan kepercayaan terhadap mereka untuk mencapai sasaran.

Dalam pelaksanaan program ekstrakurikuler bahasa Arab (kbithabah, Olimpiade Bahasa Arab, Cerdas Cermat Bahasa Arab, taqdimul qishshah, dan fabmil Qur'an), kepala bidang ekstrakurikuler selaku atasan yang membawahi banyak bidang, menerapkan langkah-langkah George dalam memilih pelatih dan mempercayakan proses pembelajaran ekstrakurikuler kepada mereka. Sumber daya manusia menjadi faktor utama keberhasilan pelaksanaan sebuah program. Konsistensi pelatih dan anggota ekstrakurikuler yang tinggi menjadikan program ini berjalan dengan baik sesuai dengan tujuan dan keinginan bersama. Pelatih membimbing, mengarahkan, dan menjelaskan pengetahuan sesuai dengan jenis ekstrakurikuler masing-masing. Hal ini dibuktikan dengan keikutsertaan siswi dalam perlombaan, di antara lomba yang diikuti adalah lomba PORSEMANAS (Pekan Olahraga Seni Ma'arif Nasional), AKSIOMA Tingkat Daerah, IONIC (Islamic Olympiad and Islam Competition), lomba nasional yang diadakan oleh kampus di Malang seperti Gaza (Gebyar Apresiasi Khazanah Arabi) di UIN, dan PA (Pekan Arabi) di UM. Siswi tidak takut dan tidak malu untuk mengikuti perlombaan yang diselenggarakan oleh instansi-instansi di atas dengan predikat menang atau kalah, karena orientasi sekolah adalah menitikberatkan pada pengalaman dan pembentukan karakter siswi walaupun ekstrakurikuler di MA Pesantren Nurul Ulum usianya sangat muda.

Manajemen dengan mewajibkan santri untuk mengikuti ekstrakurikuler tersebut baru diterapkan pada tahun 2018, sedangkan ekstrakurikuler sendiri dibentuk pada tahun 2017. Yang melatarbelakangi dibentuknya ekstrakurikuler ini adalah kegiatan kebahasaan berupa lomba-lomba bahasa Arab yang diadakan oleh banyak pihak. Alasan tersebut juga memotivasi siswi untuk dapat bersaing tidak hanya di sekolah, melainkan juga antar sekolah. Pada tahun 2017, evaluasi pembelajaran dilakukan dua kali yaitu pada akhir pembelajaran di semester pertama dan akhir semester kedua. Seiring dengan diwajibkan ekstrakurikuler di MA Pesantren Nurul Ulum dan sedang berjalan saat ini, pelaksanaan program ekstrakurikuler ini semakin terarah tujuan dan proses pembelajarannya. Dengan demikian menjadikan siswi lebih peka terhadap lingkungan sekitar dengan mengadakan kegiatan sendiri di luar kurikulum sekolah dan ekstrakurikuler berupa belajar kelompok yang dimentori oleh temannya sendiri yang berasal dari anggota ekstrakurikuler. Hal ini sesuai dengan pendapat Direktorat Pendidikan Menengah Kejuruan Suryosubroto bahwa ruang lingkup kegiatan ekstrakurikuler harus bertumpu pada kegiatan yang bisa membantu program intra-kurikuler dan kurikuler. $^{24}$

${ }^{24}$ Suryosubroto. Proses Belajar Mengajar di Sekolah, (Jakarta: PT Rineka Cipta, 2009), hlm. 288. 
Menurut hasil wawancara dengan salah satu pelatih ekstrakurikuler yaitu ustadzah ANA dan hasil observasi, empat ekstrakurikuler bahasa Arab di atas memiliki bentuk atau model yang variatif dalam pelaksanaan pembelajarannya. Dilihat dari tujuan dan jenis ekstrakurikuler yang berbeda-beda, model yang digunakan juga berbeda-beda.

Kegiatan ekstrakurikuler Khithabah beranggotakan 12 siswi dengan satu pelatih yang biasa kita panggil ustadzah, yaitu ustadzah YAT. Dengan jumlah yang relatif tidak banyak, maka pembelajaran memberi manfaat yang signifikan. Proses pelaksanaan program ekstrakurikuler ini dengan sistem ceramah dan praktek, pada pertemuan pertama ustadzah memberikan materi berupa teks pidato dan materi public speaking secara umum dan kiat-kiat untuk menghilangkan perasaan ragu dan takut, dilanjutkan dengan menerjemahkan dan praktek. Dalam praktek pidato, santri berlatih untuk berpidato di hadapan teman-teman terlebih dahulu, dan kemudian mendapatkan masukan dari teman dan ustadzah terkait penampilannya.

Ekstrakurikuler ini menggunakan Model Kooperatif, karena lebih menitikberatkan pada kemampuan berpikir santri, penyelesaian masalah, dan mempraktekkan kemampuannya. Khithabah tepat dilaksanakan dengan Model Kooperatif karena kegiatan ini mengedepankan kesadaran siswa agar belajar berpikir, menemukan solusi, mempraktikkan pengetahuannya, dan refleksi terhadap jalan pemikirannya sehingga ia ikut berpartisipasi memberikan pengetahuannya kepada anggota lain ${ }^{25}$.

Ekstrakurikuler Olimpiade Bahasa Arab yang beranggotakan 15 siswi dari bermacam tingkatan baik kelas X, XI, atau XII dengan pelatih ustadzah ISN. Proses pelaksanaan ekstrakurikuler ini yaitu dengan mengerjakan soal-soal, dan penjelasan terkait soal yang sulit dan atau terkait dengan tema-tema yang butuh untuk penjelasan ulang. Proses pembelajaran sangat terasa efeknya pada pemahaman santri mengingat jumlah pesertanya tidak banyak, proses pembelajarannya terlihat seperti sistem privat berbentuk kelompok.

Ekstrakurikuler ini sebagaimana kegiatan kbithabah juga menggunakan Model Kooperatif dengan mengutamakan kesadaran siswa agar mampu belajar berpikir, menyelesaikan masalah, dan mempraktikkan pengetahuannya, adapun praktek dalam khithabah dan olimpiade berbeda, yakni dalam olimpiade santri mempraktekkan pengetahuan dengan cara belajar bersama teman sejawat dengan mengadakan balaqah kecil.

Ekstrakurikuler Cerdas Cermat bahasa Arab yang biasa kita sebut dengan istilah "imathoh" ini beranggotakan 11 siswi dengan pelatih ustadzah ANA. Ustadzah memberikan materi dengan model yang beragam, ia memberi materi dengan metode ceramah dan permainan. Metode ceramah biasa 
digunakan untuk menjelaskan tentang kaidah-kaidah atau tentang pengetahuan Islam, sedangkan untuk latihan mufrodat dan tebak gambar tokoh dikemas dalam bentuk lu'bah lughowiyyah, seperti dalam pembelajaran mufrodat yang didesain dengan permainan eat bulaga, dan gambar tokoh dengan wasfu as-shuroh, atau latihan maharah istima' dengan model permainan missing lyric.

Dari beberapa model yang digunakan oleh pelatih, maka secara tidak langsung para santri menikmati proses pelaksanaan ekstrakurikuler dan tidak merasa jenuh dengan satu model pembelajaran saja, mengingat materi dalam cerdas cermat bahasa Arab yang beragam.

Ekstrakurikuler ini menggunakan Model Komunikatif-Eklektik atau Metode Campuran karena tidak tertumpu pada kegiatan tunggal namun bervariatif sehingga metode ini membuat kegiatan pembelajaran menumbuhkan motivasi peserta didik ${ }^{26}$. Pelaksanaan kegiatan ini juga menggunakan model Quantum karena menggunakan berbagai macam interaksi dan relevansi ${ }^{27}$, yakni antara contoh model permainan, pembahasan soal, dan Metode Ceramah, sehingga suasana menjadi meriah dan tidak membosankan. Metode ini melahirkan kegiatan yang mengasah pemikiran dan kekuatan ingatan, bermanfaat dan menyenangkan ${ }^{28}$.

Kegiatan ekstrakurikuler ini beranggotakan 5 siswi dengan pelatih ustadzah UM. Jumlah yang relatif sedikit ini menjadi nilai lebih bagi siswa agar fokus dan efektif dalam menyerap materi yang diberikan pelatih. Kegiatan ini menitikberatkan pada praktek karena pembelajarannya terkait dengan mimik, emosi, dan intonasi yang titik-beratnya ada pada penampilan dengan tetap memperhatikan labjah lughowiyyah dan teks cerita.

Model pembelajaran yang digunakan Ustadzah adalah dengan menghafal teks dan memberi contoh yakni mempraktekan sebuah cerita yang kemudian dicontoh oleh para siswi. Praktek pada taqdimul qisshoh ini di desain seperti mengikuti perlombaan, siswi harus tampil maksimal dengan menyiapkan atribut atau properti sebagai pendukung penampilan mereka yang mana properti ini dibuat secara bersama-sama.

Ekstrakurikuler Taqdimul Qishshah seperti pada kegiatan pertama dan kedua yang juga menggunakan Model Kooperatif karena kegiatan ini melatih siswa berpikir dan mempraktikkan pengetahuannya berupa pemahaman teks Arab yang diperluas menjadi drama tunggal dan lain sebagainya.

\footnotetext{
${ }^{26}$ Acep Hermawan, op.cit., hlm. 198.

27 B. De Porter, M. Reardon, dan SS. Nourie, op.cit., hlm. 32.

28 Jumadi, op.cit., hlm 80.
} 


\section{Penutup}

Berdasarkan pada hasil penelitian ini maka dapat disimpulkan bahwa; pertama, Madrasah Aliyah Nurul Ulum memiliki empat program ekstrakurikuler bahasa Arab, yakni ekstrakurikuler kbithabah, ekstrakurikuler olimpiade bahasa Arab, ekstrakurikuler cerdas cermat, dan ekstrakurikuler taqdimul qishshah. Pelaksanaan seluruh program ini terbilang baru karena telah dilaksanakan lebih kurang satu tahun. Pelaksanaannya diawasi langsung oleh para guru sekaligus pembimbing ekstrakurikuler. Meski begitu, kendala dalam pelaksanaan program ini justru muncul ketika ada sebagian pembimbing tidak ikut serta dalam kegiatan ekstrakurikuler yang ia pegang. Kedua, berbagai model pembelajaran bahasa digunakan dalam setiap kegiatan ekstrakurikuler Madrasah Aliyah Nurul Ulum. Model Kooperatif digunakan dalam ekstrakurikuler Olimpiade Bahasa Arab, ekstrakurikuler Taqdimul Qishshah, dan ekstrakurikuler Khithabah. Sedangkan Model Komunikatif-Eklektik dan Quantum digunakan dalam ekstrakurikuler Cerdas Cermat. Adapun Metode Kontekstual tidak digunakan dalam seluruh kegiatan ekstrakurikuler di sekolah ini karena tidak mengarahkan pembelajaran bahasa Arab siswa kepada pendekatan kontekstual. Model-model pembelajaran ini sangat baik direalisasikan secara keseluruhan dalam pendidikan bahasa Arab karena dengan gaya atau model pembelajaran yang beragam proses belajar mengajar akan berwarna bagi guru dan siswa dan tentu saja sekaligus mengasah kompetensi siswa. Penelitian ini sesungguhnya terbatas pada model pelaksanaan program saja. Maka peneliti menyarankan kepada peneliti selanjutnya agar mengembangkan penelitian ini dengan pilihan untuk fokus pada hubungan model-model yang digunakan dan grafik prestasi siswa atau pada sisi lain seperti pembelajaran bahasa Arab dalam kelas dan model-modelnya.

\section{Bibliografi}

Ahmadi, Maswan, Kurnia Istita'ah, Nur Rahmah Sholihah, dan Zakiyah Arifah. "Penggerakan Program Bahasa Arab di Pondok Pesantren Modern". Arabi: Journal of Arabic Studies, Vol. 3, No. 1 (2018).

Baharuddin dan Moh. Makin. Manajemen Pendidikan Islam. Malang: UIN Maliki Press, 2016.

De Porter, B., M. Reardon, dan SS. Nourie. Quantum Teaching (Mempraktikkan Quantum Learning di Ruang-ruang Kelas). Terjemahan Ary Nilandari. Bandung: Kaifa, 2014.

Hermawan, Acep. Metodologi Pembelajaran Bahasa Arab. Bandung: Remaja Rosdakarya, 2011.

Izzan, Ahmad. Metodologi Pembelajaran Bahasa Arab. Bandung: Humaniora, 2009. 
Jumadi. "Peningkatan Pemahaman Siswa Materi Kenampakan Alam Melalui Model Quantum Learning Siswa Kelas IV SDN Gebangsari 01 Semarang Tahun Ajaran 2010/2011”. Jurnal Media Penelitian Pendidikan, Vol. 6, No. 2 (2012).

Lindarti, Achmad A. Hinduan, dan Raden Oktova. "Penerapan Pembelajaran Kooperatif STAD (Student Teams Achievement Division) dalam Upaya Meningkatkan Hasil Belajar Fisika pada Konsep Optika Geometris Kelas X SMA”. Jurnal BFI, Vol. 2, No. 2 (2010).

Lubis, Amri Yusuf. "Pelaksanaan Manajemen Kurikulum pada SMA Negeri 1 Buengcala Kabupaten Aceh Besar". Jurnal Administrasi Pendidikan Pascasarjana Universitas Syiah Kuala. Vol. 3, No. 1 (2015).

Saputra, M. Yudha. Pengembangan Kegiatan Ko dan Ekstrakurikuler. Jakarta: Depdiknas, 1998.

Sugiono. "Meningkatkan Hasil Belajar Bahasa Indonesia Materi Melaporkan Isi Buku Melalui Pendekatan Komunikatif Metode SQ2R pada Siswa Kelas 6 SDN Kramat Sukoharjo 03 Jember". Jurnal Pancaran Pendidikan, Vol. 3, No. 3 (2014).

Sugiyono. Metode Penelitian Kualitatif, Kuantitatif, dan R\&D. Bandung: IKAPI, 2017.

Suryosubroto. Proses Belajar Mengajar di Sekolah, Jakarta: PT Rineka Cipta, 2009.

Sumiati dan Asra. Metode Pembelajaran. Bandung: CV. Wacana Prima, 2009.

Uzer, Moh. dan Lilis. Upaya Optimalisasi Kegiatan Belajar Mengajar. Bandung: PT. Remaja Rosdakarya, 1993.

Viningsih, Sus Ria. "Pelaksanaan Program Pengembangan Diri Siswa di Sekolah Menengah Atas Negeri 1 Timpeh Kecamatan Timpeh Kabupaten Dharmasraya". Jurnal Bahana Manajemen Pendidikan, Vol. 1, No. 1 (2013).

Wagiran. "Meningkatkan Keaktifan Mahasiswa dan Reduksi Miskonsepsi Melalui Pembelajaran Konstruktivistik Model Kooperatif Berbantuan Modul”. Jurnal Ilmu Pendidikan, Vol. 13, No. 1 (2006).

Wiyani, Novan Ardy. Menumbuhkan Pendidikan Karakter di SD (Konsep, Praktek dan Strategi). Jogjakarta: Ar-Ruzz Media, 2013.

https:// nurululum.wordpress.com/ma-nurul-ulum/ 
46 | Arabiyatuna : Jurnal Bahasa Arab, Vol. 3, No. 1, 2019 